\title{
STUDI PENGEMBANGAN MODEL HIDROGRAF SATUAN SISTETIS SNYDER UNTUK SUNGAI -SUNGAI DI SULAWESI SELATAN
}

\author{
MUHAMAD YAMIN
}

\author{
Fakultas Teknik UNMAS Mataram \\ e-mail: sumberdayaair8@gmail.com
}

\begin{abstract}
ABSTRAK
Penelitian ini bertujuan untuk menganalisis parameter-parameter yang berpengaruh pada metode hidrograf satuan sintetis Snyder. Penelitian dilakukan pada 11 DAS di Propinsi Sulawesi Selatan, 8 DASuntuk pemodelan dan 3 DAS lainnya untuk tes keandalan (verifikasi model).

Dengan data hujan, data debit dan karakteristik DAS yang diperoleh dari masing-masing DAS dilakukan analisis terhadap parameter-parameter yang berpengaruh pada peambatan hidrograf darimetode HSS Snyder. Kemudian dibandingkan dengan hidrograf satuan pengamatan yang dianalisis dengan metode Collins.

Setelah dilakukan kalibrasi didasakan dengan kriteria NASH diperoleh Waktu Puncak $(\mathrm{Tp})=$ 97.996\%; Debit Puncak $(\mathrm{Qp})=98.331 \%$ dan Waktu Dasar $(\mathrm{Tb})=99.700 \%$. Penggambaran lengkung hidrograf menggunakan titik bantu $\mathrm{W}$, dimana memberikan hasil penyimpangan volume yaitu: $7.980 \%, 9.227 \% ; 6.855 \% ; 4.966 \% ; 10.972 \%$ dan $9.843 \%$ ini relatif kecil bila dibandingkan model dengan menggunakan Lengkung Alexejeyev dengan penyimpangan : $22.362 \% ; 29.991 \%$; 26.319\%; 19.602\%; $29.786 \%$ dan $17.633 \%$.
\end{abstract}

Kata kunci : Hidrograf Satuan Sintetis, Sungai, karakteristik DAS

\section{ABSTRACT}

This study aims to analyze the parameters that influence the Snyder synthetic unit hydrograph method. The study was conducted on 11 watersheds in South Sulawesi Province, 8 watersheds for modeling and 3 other watersheds for reliability testing (model verification).

With rainfall data, the discharge data and watershed characteristics obtained from each watershed were analyzed for parameters that affected the hydrograph breakdown of the Snyder HSS method. Then compared to the hydrograph of the observation unit which was analyzed by the Collins method.

After calibration was done with the NASH criteria obtained Peak Time $(T p)=97.996 \%$; Peak Discharge $(Q p)=98.331 \%$ and Basic Time $(\mathrm{Tb})=99.700 \%$. The curved delineation of the hydrograph uses the auxiliary point $W$, which gives the result of volume deviation, namely: 7.980\%, 9.227\%; 6.855\%; 4.966\%; $10.972 \%$ and $9.843 \%$ are relatively small when compared to the model using Alexejeyev Arch with deviations: $22.362 \% ; 29.991 \% ; 26,319 \% ; 19.602 \% ; 29,786 \%$ and $17,633 \%$.

Keywords: Synthetic Unit Hydrograph, River, watershed characteristics

\section{PENDAHULUAN}

\section{Latar Belakang}

Penentuan banjir rancangan memberikan hasil yang bermanfaat bila disajikan dalam bentuk hidrograf banjir. Informasi yang dapat diberikan dari hasil [engalihragaman hujan menjadi hidrograf limpasan akan lebih banyak. Salah satu cara yang selama ini dianggap baik adalah penurunan hidrograf satuan dari hidrograf banjir pengamatan merupakan kendala utama yang dihadapi akhir-akhir ini. Akhirnya 
dikembangkan penurunan hidrograf yang didasarkan sintetis parameter bentuk aliran sungai yang dikenal dengan hidrograf sintetis (Bisri dan Andawayanti,1995)

Tidak semua Daerah Aliran Sungai (DAS) mempunyai data pengukuran debit yang dapat digunakan sebagai dasar untuk menurunkan hidrograf satuan. Dengan demikian berkembang penurunan hidrograf satuan sintetis yang didasarkan atas karakeristik fisik dari suatu DAS. Hidrograf satuan yang diturunkan berdasarkan data hujan dan data debit hanya berlaku untuk daerah aliran sungai yang dimaksud dan untuk titik disungai dimana data debit diukur. Untuk titik lain disungai yang sama atau untuk DAS yang tidak mempunyai hidrograf satuan dapat digunakan model hidrograf satuan yang dikembangkan berdasarkan karakteristik fisik DAS yang dikenal dengan istilah Hidrograf Satuan Sintetis atau disingkat HSS (Chow,1988)

\section{Identifikasi Masalah}

Metode hidrograf satuan sintetis telah banyak dikembangkan oleh para pakar,antara lain Hidrograf Satuan Sintetis (HSS) Snyder yang dikembangkan berdasarkan karakteristik DAS-DAS di dataran tinggi Appalachian Amerika Serikat oleh F.F. Snyder bila diterapkan pada suatu DAS di Indonesia belum tentu sesuai. Hal ini disebabkan karena adanya perbedaan karakteristik, kondisi dan pola hujan antara DAS-DAS di Indonesia (khususnya di Sulawesi Selatan) dengan daerah diaman metode ini dikembangkan.

Dalam metode HSS Snyder termuat 2 parameter non fisik yaitu $\mathrm{Ct}$ dan $\mathrm{Cp}$ dimana merupakan koefisien-koefisien yang bergantung pada satuan DAS (Wilson,1993). Berdasarkan nilai Ct dan Cp harus ditentukan secara empirik, karena besarnya berubah-rubah antara daerah yang satu dengan yang lain. Dengan demikian maka terjadi kesulitan dalam pemakaian metode tersebut,khususnya pemakaian pada sungai-sungai di Sulawesi selatan.

Untuk lebih dapat diterima di daerah penelitian (Propinsi Sulawesi Selatan), maka metode HSS Snyder harus disesuaikan denga karakteristik dan kondisi setempat. Penelitian ini menggunakan sejumlah DAS di Sulawesi Selatan yang dianggap memenuhi syarat untuk diteliti dan mewakili kondisi yang ada,sehingga diharapkan memperoleh suatu perumusan banjir yang memadai.

\section{Rumusan Masalah}

Dari identifikasi permasalah tersebut di atas, dapat dirumuskan masalah sebagai berikut:

1. Bagaiman bentuk hidrograf satuan yang telah diturunkan dari debit banjir pengamatan di daerah penelitia?

2. Penyesuain model HSS Snyder yang mendekati bentuk hidrograf satuan yang diturunkan dari debit banjir pengamatan di daerah penelitian?

3. Berapa besar tingkat sensivitas dari parameter=parameter DAS terhadap unsur-unsur HSS Snyder yang telah disesuaikan dengan kondisi daerah setempat?

\section{Tujuan dan Kegunaan Penelitian}

Secara umum tujuan penelitian ini adalah untuk mendapatkan suatu model peramalan debit banjir secara sintetisyang memadai untuk sungai-sungai di Sulawesi Selatan yang belum terdapat pengukuran. Secara khusus penelitian ini bertujuan untuk:

1. Menambah wawasan keilmuan dan mengembangkan ilmu hidrologi terutama dalam hal parameter debit banjir secara sintetis.

2. Mempermudah penggunaan HSS Snyder untuk DAS pada sungai di Propinsi Sulawesi Selatan dengan tingkat keandalan yang memadai

3. Sebagai alat bantu untuk menghitung debit banjir rancangan dengan parameter yang sesuai guna perencanaan bangunan air.

Adapun kegunaan dari penelitian ini adalah untuk memberikan masukan yang relatif akurat bagi para perencana, praktisi dan semua pihak yang berkepentingan dengan perencanan bangunan pengairan berupa:

1. Bentuk hidrograf satuan sintetis untuk memprediksi debit banjir secara sintetis dengan tingkat keakuratan yang memadai

2. Sebagai dasar untuk keperluan perencanaan dalam proyek-proyek pengairan di Propinsi Sulawesi Selatan

3. Sebagai motivasi untuk pengembangan penelitian lebih lanjut guna mendapatkan rumusan-rumusan yang sejenis dalam bidang hidrologi khususnya dalam hal analisa perkiraan debit banjir. 


\section{METODE PENELITIAN}

\section{Lokasi Penelitian}

Penelitian ini mengambil lokasi pada sejumlah sungai di Sulawesi selatan. Lokasi yang dipilih adalah merupakan satu kesatuan Wilayah Sungai, yaitu satuan Wilayah Sungai Jeneberang karena mempunyai data pengamatan yang cukup memadai. Pemilihan lokasi ini didasarkan atas ketersediaan dan kelengkapan data yang dapat menunjang akurasi dari hasil penelitian. Secara umum pada daerah penelitian disyaratkan:

1. Terdapat data pengukuran debit (AWLR)

2. Terdpat data pencatatan hujan dari alat penakar hujan manual dan otomatis

3. Tidak terdapat waduk/tampungan dibagian hulu dari stasiun hidrometri (AWLR) pada DAS yang bersangkutan

\section{Pengumpulan Data}

Dalam penelitian ini data yang digunakan merupakan data karakteristik DAS, peta topografi, data AWLR, data pengukuran hujan otomatis, dan data pengukuran hujan manual dari masing-masing DAS yang diteliti. Data-data tersebut diperoleh dari Dinas Pengairan dan Proyek Pengelolaan Sumber Air dan Pengendalian Banjir tingkat I Propinsi Sulawesi Selatan

\section{Tahapan Penelitian}

Secara garis besar penelitian ini terdiri dari 5 tahapan:

1. Analisis data karakteristik DAS (peta topografi), data curah hujan dan data pengukran AWLR

2. Analisis hidrograf satuan dari tiap-tiap DAS yang diteliti

3. Penyesuaian HSS Snyder di daerah penelitian

4. Tes keandalan hasil penelitian

5. Membuat kesimpuln dan saran

\section{HASIL ANALISA DATA DAN PEMODELAN}

DAS yang digunakan dalam penelitian dari kegiatan pengumpulan data diperoleh 12 data DAS yang ada di Sulawesi Selatan dengan luas dibawah $800 \mathrm{~km}^{2}$.

Tabel: 1 Data DAS yang diteliti beserta luasnya

\begin{tabular}{|c|l|c|c|}
\hline No & \multicolumn{1}{|c|}{ Nama Sungai } & $\begin{array}{c}\text { SWS } \\
\text { (Satuan Wilayah Sungai) }\end{array}$ & ${\text { Luas }(\mathrm{km})^{2}}^{2}$ \\
\hline 1. & Maros & Jeneberang & 601 \\
2. & Tallo & Jeneberang & 369 \\
3. & Jeneberang & Jeneberang & 757 \\
4. & Pamukkulu & Jeneberang & 390 \\
5. & Allu & Jeneberang & 121 \\
6. & Kellara & Jeneberang & 508.29 \\
7. & Bialo & Jeneberang & 152 \\
8 & Balangtieng & Jeneberang & 208 \\
9. & Lolisang & Jeneberang & 182.61 \\
10. & Tangka & Jeneberang & 102.60 \\
11. & Tamanroya & Jeneberang & 136 \\
12. & Tino & Jeneberang & 63 \\
\hline
\end{tabular}

Sumber: Hasil Analisis

Dari sejumlah data sungai DAS yang diperoleh tidak semuanya memenuhi syarat untuk diteliti. Satu buah suangai yaitu sungai Lolisang tidak digunakan dalam penelitian, karena sungai tersebut penelitintidak mendapatkan data-data seperti AWLR, karateristik DAS yang dapat mewakili kondisi dilapangan. Dalam penelitian ini peneliti hanya menggunakan 11 DAS, 8 data DAS untuk pemodelan dan 3 data DAS untuk tes keandalan (verifikasi model). Selain luas DAS beberapa parameter yang diteliti dapat dilihat pada tabel berikut: 
Tabel: 2 Nilai-nilai parameter DAS yang diteliti

\begin{tabular}{|c|l|c|c|c|c|c|c|}
\hline No & \multicolumn{1}{|c|}{ Nama DAS } & $\begin{array}{c}\mathrm{A} \\
(\mathrm{km})^{2}\end{array}$ & $\begin{array}{c}\mathrm{L} \\
(\mathrm{km})\end{array}$ & $\begin{array}{c}\mathrm{L}_{\mathrm{c}} \\
(\mathrm{km})\end{array}$ & $\begin{array}{c}\mathrm{L}_{\mathrm{b}} \\
(\mathrm{km})\end{array}$ & $\mathrm{S}$ & $\mathrm{F}_{\mathrm{c}}$ \\
\hline 1. & Maros & 601 & 65 & 32.39 & 51.135 & 0.0230 & 0.142 \\
2. & Tallo & 369 & 61 & 24.63 & 43.750 & 0.3100 & 0.099 \\
3. & Jeneberang & 757 & 80 & 35.75 & 76.250 & 0.0195 & 0.118 \\
4. & Pamukkulu & 390 & 42 & 25.43 & 41.00 & 0.0300 & 0.221 \\
5. & Allu & 121 & 28 & 13.20 & 27.210 & 0.0660 & 0.154 \\
6. & Kellara & 508.29 & 70 & 25.53 & 64.125 & 0.0350 & 0.075 \\
7. & Tangka & 203 & 53 & 21.72 & 43.22 & 0.0431 & 0.072 \\
8 & Tamanroya & 244 & 70 & 24.32 & 59.49 & 0.0263 & 0.048 \\
\hline
\end{tabular}

Sumber: Hasil Analisis

Tabel: 3 (Lanjutan)

\begin{tabular}{|c|l|c|c|c|}
\hline No & \multicolumn{1}{|c|}{ Nama DAS } & $\mathrm{K}(\mathrm{km})$ & $\mathrm{W}_{\mathrm{r}}(\mathrm{km})$ & $\mathrm{A}_{\mathrm{i}}(\mathrm{km})$ \\
\hline 1. & Maros & 145.625 & 17.045 & 77.67 \\
2. & Tallo & 95.251 & 14.583 & 65.34 \\
3. & Jeneberang & 157.135 & 25.417 & 97.55 \\
4. & Pamukkulu & 95.325 & 13.677 & 56.93 \\
5. & Allu & 57.462 & 8.851 & 35.81 \\
6. & Kellara & 125.325 & 21.375 & 62.70 \\
7. & Tangka & 46.385 & 18.731 & 20.925 \\
8 & Tamanroya & 102.179 & 22.371 & 58.735 \\
\hline
\end{tabular}

Sumber: Hasil Analisis

Dimana:
A $\quad=$ Luas DAS $(\mathrm{km})^{2}$
$\mathrm{L} \quad=$ Panjang sungai utama $(\mathrm{km})$
$\mathrm{L}_{\mathrm{c}} \quad=$ Panjang sungai utama diukur dari tempat pengukuan samapai titik disungai utama yang terdekat dengan titik berat DAS $(\mathrm{km})$
$\mathrm{L}_{\mathrm{b}} \quad=$ Panjang DAS maksimum sepanjang aliran sungai utama $(\mathrm{km})$
$\mathrm{S} \quad=$ Kemiringan rata-rata sungai utama
$\mathrm{K} \quad=$ Keliling DAS $(\mathrm{km})$
FD $\quad=$ Faktor bentuk; FD $=$ K/A (Suwignyo, 2000)
$\mathrm{A}_{\mathrm{i}} \quad=$ Luas DAS sebelah hilir $(\mathrm{km})^{2}$
$\mathrm{W}_{\mathrm{r}} \quad=$ Lebar rata-rata DAS sepanjang aliran sungai utama, yaitu rata-rata dari lebar DAS
pada $1 / 4$ panjamg sungai (W.25.L), 3/4 panjamg sungai (W.75.L) dan pada titik disungi utama yang terdekat dengan titik berat DAS (Wc) Km, pengukuran dilakukan dari stasiun AWLR

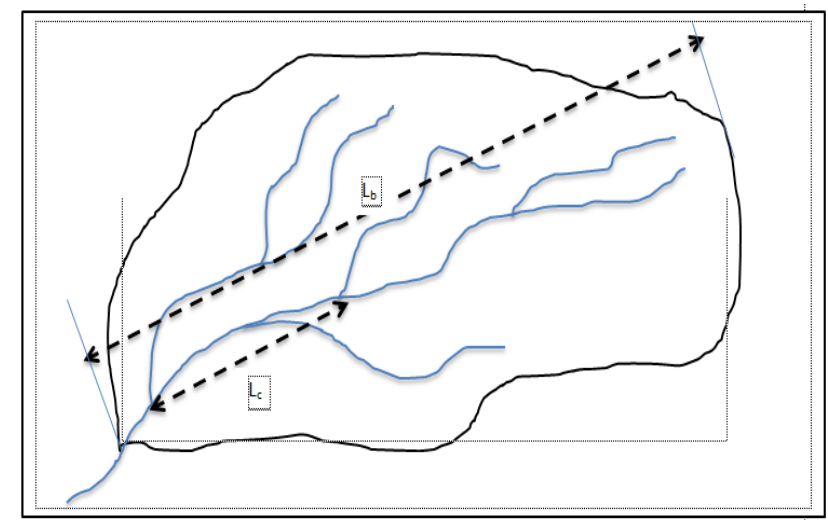

Gambar: 1 Sketsa penetapan 


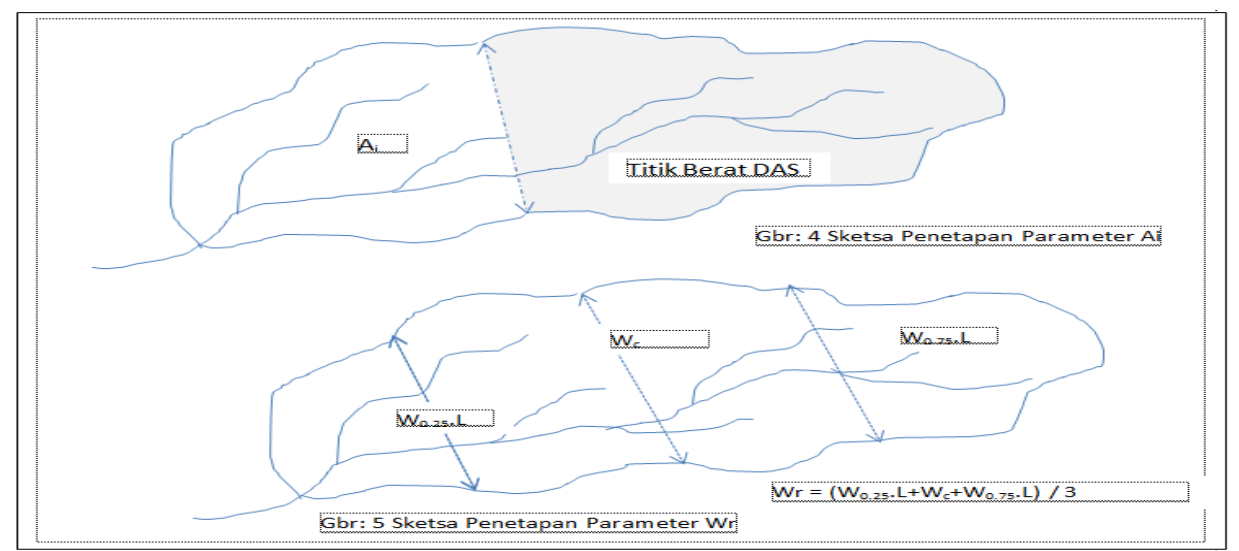

Gbr: 2 Sketsa Penetapan Parameter Wr

Hidrograf yang dihitung untuk setiap kasus banjir belum merupakan hidrograf satuan yang dapat dianggap mewakili DAS yang bersangkutan. Untuk ini diperlukan hidrograf satuan yang diturunkan dari banyaknya kasus banjir, kemudian dirata-ratakan untuk memperoleh hidrograf satuan yang dianggap mewakili DAS yang bersangkutan. Rata-rata tersebut bukan rata-rata aritmetika tetapi hanya puncaknya saja yang dirata-ratakan. Untuk lengkung kurva hidrograf satuan disesuaikan dengan kira-kira ditengah antara kasus banjir tersebut (Mulyani,1993). Unsur-unsur hidrograf satuan yang meliputi $\mathrm{T}_{\mathrm{p}}$ (Waktu Puncak), $\mathrm{Q}_{\mathrm{p}}$ (Debit Puncak) dan $\mathrm{T}_{\mathrm{b}}$ (Waktu Dasar). Dari masing-masing DAS dapat disajikan dalam tabel berikut:

Tabel: 4 Unsur-unsur hidrograf satuan pada sungai/DAS yang diteliti

\begin{tabular}{|c|l|c|c|c|}
\hline No & \multicolumn{1}{|c|}{ Nama DAS } & $\begin{array}{c}\mathrm{Q}_{\mathrm{p}} \\
\left(\mathrm{m}^{3} / \mathrm{det}\right)\end{array}$ & $\begin{array}{c}\mathrm{T}_{\mathrm{p}} \\
(\mathrm{jam})\end{array}$ & $\begin{array}{c}\mathrm{T}_{\mathrm{b}} \\
(\mathrm{jam})\end{array}$ \\
\hline 1. & Maros & 20.971 & 7.448 & 45 \\
2. & Tallo & 22.500 & 6.310 & 34 \\
3. & Jeneberang & 23.285 & 8.233 & 36 \\
4. & Pamukkulu & 15.350 & 5.076 & 32 \\
5. & Allu & 10.560 & 5.025 & 21 \\
6. & Kellara & 12.530 & 9.000 & 42 \\
7. & Tangka & 7.472 & 3.261 & 18 \\
8 & Tamanroya & 8.474 & 5.000 & 25 \\
\hline
\end{tabular}

Sumber: Hasil Analisis

Tabel: 5 Unsur Hidrograf Satuan Sintetis Snyder

\begin{tabular}{|c|l|c|c|c|c|c|c|}
\hline No & \multicolumn{1}{|c|}{ Nama DAS } & $\begin{array}{c}\mathrm{A} \\
(\mathrm{km})^{2}\end{array}$ & $\begin{array}{c}\mathrm{L} \\
(\mathrm{km})\end{array}$ & $\begin{array}{c}\mathrm{L}_{\mathrm{c}} \\
(\mathrm{km})\end{array}$ & $\begin{array}{c}\mathrm{Q}_{\mathrm{p}} \\
\left(\mathrm{m}^{3} / \mathrm{det}\right)\end{array}$ & $\begin{array}{c}\mathrm{T}_{\mathrm{p}} \\
(\mathrm{jam})\end{array}$ & $\begin{array}{c}\mathrm{T}_{\mathrm{b}} \\
(\mathrm{jam})\end{array}$ \\
\hline 1. & Maros & 601 & 65 & 32.39 & 19.244 & 7.851 & 52.762 \\
2. & Tallo & 369 & 61 & 24.63 & 12.853 & 7.175 & 47.478 \\
3. & Jeneberang & 757 & 80 & 35.75 & 21.884 & 8.609 & 58.499 \\
4. & Pamukkulu & 390 & 42 & 25.43 & 21.036 & 4.641 & 31.474 \\
5. & Allu & 121 & 28 & 13.20 & 6.094 & 4.968 & 31.667 \\
6. & Kellara & 508.29 & 70 & 25.53 & 12.354 & 7.443 & 49.148 \\
7. & Tangka & 203 & 53 & 21.72 & 7.472 & 3.261 & 18.265 \\
8 & Tamanroya & 244 & 70 & 24.32 & 8.474 & 5.000 & 25.327 \\
\hline
\end{tabular}

Sumber: Hasil Perhitungan

Hasil perhitungan yang disajikan pada tabel 5 jelas sekali terjadi penyimpangan yang besar jika dibandingkan dengan data pengamatan di daerah studi pada tabel 4. Ketidak akuratan tersebut mungkin disebabkan oleh kondisi, pola hujan dan karakteristik DAS didaerah penelitian tidak sama dengan daerah dimana metode ini dikembangkan. Disamping itu estimasi harga $\mathrm{C}_{\mathrm{t}}$ dan $\mathrm{Cp}$ mungkin kurang cocok dilapangan di daerah penelitian.

Persamaan-persamaan yang dibuat oleh Snyder ini penggunaannya dibatasi untuk daerah dataran tinggi Appalachian Amerika Serikat dengan luas DAS yang digunakan untuk pemodelan mencapai $30.000 \mathrm{~km}^{2}$ (Sri 
Harto,1985). Untukdapat digunakan di daerah studi hidrograf satuan sintetis Snyder harus dimodelkan/disesuaikan dengan kondisi pola hujan, dan karakteristik daerah setempat.

\section{Kalibrasi}

Setelah diperoleh model regresi terpilih dari waktu puncak $\left(T_{p}\right)$, debit puncak $\left(Q_{p}\right)$ dan waktu dasar $\left(T_{b}\right)$, tahapan selanjutnya adalah dilakukan kalibrasi model ini adalah untuk memeriksa ketepatan-ketepan parameter hidrograf satuan yang dimodelkan. Kalibrasi parameter ini didasarkan pada ketelitian NASH

$\mathrm{KN}=\left[1-\frac{\sum_{i=1}^{n}(Q p i-Q m i)^{2}}{\sum_{i=1}^{n}(Q p i-Q p i)^{2}}\right] x 100 \%$

Dimana:

$\mathrm{Q}_{\mathrm{pi}} \quad=$ Debit puncak pengamatan ke-i $\left(\mathrm{m}^{3} / \mathrm{det}\right)$

$\mathrm{Q}_{\mathrm{mi}} \quad=$ Debit puncak model ke-i $\left(\mathrm{m}^{3} / \mathrm{det}\right)$

$\mathrm{Q}_{\mathrm{pi}} \quad=$ Debit puncak pengamatan rata-rata $\left(\mathrm{m}^{3} / \mathrm{det}\right)$

Dari proses kalibrasi yang dilakukan diperoleh kriteria NASH untuk:

- Waktu puncak $\left(\mathrm{T}_{\mathrm{p}}\right)$

$\mathrm{KN}=97.996 \%$

- Debit puncak $\left(\mathrm{Q}_{\mathrm{p}}\right)$

$\mathrm{KN}=98.331 \%$

- Waktu Dasar $\left(\mathrm{T}_{\mathrm{b}}\right)$

$\mathrm{KN}=99.700 \%$

Tabel: 6 Kalibrasi Hasil Pemodelan Waktu Puncak $\left(\mathrm{T}_{\mathrm{p}}\right)$ Hidrograf Satuan Sintetis

\begin{tabular}{|l|c|c|c|c|c|c|c|c|c|}
\hline Nama DAS & $\begin{array}{c}\mathrm{L} \\
(\mathrm{km})\end{array}$ & $\begin{array}{c}\mathrm{L}_{\mathrm{c}} \\
(\mathrm{km})\end{array}$ & $\mathrm{S}$ & $\begin{array}{c}\mathrm{Wr} \\
(\mathrm{jam})\end{array}$ & $\begin{array}{c}\mathrm{T}_{\mathrm{p}} \mathrm{M} \\
(\mathrm{jam})\end{array}$ & $\mathrm{T}_{\mathrm{p}} \mathrm{P}(\mathrm{jam})$ & $\begin{array}{c}(\mathrm{TpP}- \\
\mathrm{pM})^{2} \\
(\mathrm{jam})\end{array}$ & $\begin{array}{c}(\mathrm{TpP}- \\
\mathrm{TpP})^{2} \\
(\mathrm{jam})\end{array}$ & $\begin{array}{c}\text { Nash } \\
(\%)\end{array}$ \\
\hline$(2)$ & $(3)$ & $(4)$ & $(5)$ & $(6)$ & $(7)$ & $(8)$ & $(9)$ & $(10)$ & $(11)$ \\
\hline Maros & 65 & 32.39 & 0.0230 & 17.045 & 6.879 & 7.448 & 0.324 & 55.473 & \\
Tallo & 61 & 24.63 & 0.3100 & 14.583 & 6.761 & 6.310 & 0.203 & 39.816 & \\
Jeneberang & 80 & 35.75 & 0.0195 & 25.417 & 8.769 & 8.233 & 0.287 & 67.782 & 97.996 \\
Pamukkulu & 42 & 25.43 & 0.0300 & 13.677 & 5.608 & 5.076 & 0.283 & 25.766 & \\
Allu & 28 & 13.20 & 0.0660 & 8.851 & 5.340 & 5.025 & 0.099 & 25.251 & \\
Kellara & 70 & 25.53 & 0.0350 & 21.375 & 10.000 & 9.000 & 1.000 & 4.628 & \\
\hline \multicolumn{1}{|l}{7.2262} & 6.8487 & 2.197 & 218.217 &
\end{tabular}

Tabel : 7 Kalibrasi Hasil Pemodelan Debit Puncak $\left(\mathrm{Q}_{\mathrm{p}}\right)$ Hidrograf Satuan Sintetis

\begin{tabular}{|l|c|c|c|c|c|c|c|c|}
\hline \multicolumn{1}{|c|}{ Nama DAS } & $\begin{array}{c}\mathrm{A} \\
(\mathrm{km})\end{array}$ & $\begin{array}{c}\mathrm{T}_{\mathrm{p}} \\
(\mathrm{jam})\end{array}$ & $\begin{array}{c}\mathrm{L} \\
(\mathrm{m})\end{array}$ & $\begin{array}{c}\mathrm{Q}_{\mathrm{p}} \mathrm{M} \\
\left(\mathrm{m}^{3} / \mathrm{det}\right)\end{array}$ & $\begin{array}{c}\mathrm{Q}_{\mathrm{p}} \mathrm{P} \\
\left(\mathrm{m}^{3} / \mathrm{det}\right)\end{array}$ & $\begin{array}{c}(\mathrm{QpP}- \\
\mathrm{QpM})^{2} \\
(\mathrm{jam})\end{array}$ & $\begin{array}{c}(\mathrm{QpP}- \\
\mathrm{QpP})^{2} \\
(\mathrm{jam})\end{array}$ & $\begin{array}{c}\text { Nash } \\
(\%)\end{array}$ \\
\hline Maros & 601 & 7.448 & 65 & 19.576 & 20.971 & 1.945 & 439.783 & \\
Tallo & 369 & 5.731 & 61 & 24.052 & 22.500 & 2.408 & 506.250 & \\
Jeneberang & 757 & 8.233 & 80 & 22.618 & 23.285 & 0.444 & 542.191 & 98.331 \\
Pamukkulu & 390 & 5.076 & 42 & 17.170 & 15.350 & 3.311 & 235.623 & \\
Allu & 121 & 4.450 & 28 & 12.493 & 10.560 & 3.736 & 111.514 & \\
Kellara & 508.29 & 5.120 & 70 & 13.750 & 12.530 & 1.488 & 157.001 & \\
\hline
\end{tabular}

Tabel : 8 Kalibrasi Hasil Pemodelan Waktu Dasar $\left(\mathrm{T}_{\mathrm{b}}\right)$ Hidrograf Satuan Sintetis

\begin{tabular}{|l|c|c|c|c|c|c|c|}
\hline \multicolumn{1}{|c|}{ Nama DAS } & $\begin{array}{c}\mathrm{Q}_{\mathrm{p}} \\
\left(\mathrm{m}^{3} / \mathrm{det}\right)\end{array}$ & $\begin{array}{c}\mathrm{T}_{\mathrm{p}} \\
(\mathrm{jam})\end{array}$ & $\begin{array}{c}\mathrm{T}_{\mathrm{b}} \mathrm{M} \\
\left(\mathrm{m}^{3} / \mathrm{det}\right)\end{array}$ & $\begin{array}{c}\mathrm{T}_{\mathrm{b}} \mathrm{P} \\
\left(\mathrm{m}^{3} / \mathrm{det}\right)\end{array}$ & $\begin{array}{c}(\mathrm{TbP}-\mathrm{TbM})^{2} \\
(\mathrm{jam})\end{array}$ & $\begin{array}{c}(\mathrm{TbP}- \\
\mathrm{TbP})^{2} \\
(\mathrm{jam})\end{array}$ & $\begin{array}{c}\text { Nash } \\
(\%)\end{array}$ \\
\hline Maros & 20.971 & 7.448 & 43.60 & 45.00 & 1.968 & 1.945 & \\
Tallo & 17.568 & 5.731 & 33.45 & 34.00 & 0.302 & 2.408 & \\
Jeneberang & 25.285 & 8.233 & 33.00 & 36.00 & 9.000 & 0.444 & 99.700 \\
Pamukkulu & 15.350 & 5.076 & 29.98 & 32.00 & 4.080 & 3.311 & \\
Allu & 9.560 & 4.450 & 20.00 & 21.00 & 1.000 & 3.736 & \\
Kellara & 16.394 & 5.120 & 43.00 & 42.00 & 1.000 & 1.488 & \\
\hline
\end{tabular}

Hasil Analisis 


\section{Verifikasi Model}

Verifikasi model dilakukan untuk mengetahui apakah model HSS Snyder yang sudah disesuaikan/dikembangkan berdasarkan karakteristik DAS pada sungai di Sulawesi selatan layak digunakan atau tidak. Verifikasi model ini dilakukan pada sungai Bialo,sungai Balangtiang dan sungai Tino, ketiga sungai ini tidak dilakukan dalam pembuatan model regresi.

Dengan menggunakan rumus-rumus dari model terpilih komponen hidrograf satuan untuk sungai Bialo, sungai Balangtieng dangai Biano dapat diperoleh hasil perhitungan seperti pada tabel 9.

Tabel: 9 Verifikasi Hasil Pengembangan Model Waktu Puncak $\left(\mathrm{T}_{\mathrm{p}}\right)$ HSS Snyder

\begin{tabular}{|l|c|c|c|c|c|c|c|c|}
\hline Nama Sungai & $\begin{array}{c}\mathrm{L} \\
(\mathrm{km})\end{array}$ & $\begin{array}{c}\mathrm{L}_{\mathrm{c}} \\
(\mathrm{km})\end{array}$ & $\mathrm{S}$ & $\begin{array}{c}\mathrm{Wr} \\
(\mathrm{km})\end{array}$ & $\begin{array}{c}\mathrm{T}_{\mathrm{p}} \mathrm{M} \\
(\mathrm{jam})\end{array}$ & $\begin{array}{c}\mathrm{T}_{\mathrm{p}} \mathrm{P} \\
(\mathrm{jam})\end{array}$ & $\begin{array}{c}\text { Penyimp } \\
(\%)\end{array}$ & $\begin{array}{c}\text { Ketelitian } \\
(\%)\end{array}$ \\
\hline Bialo & 39 & 14.99 & 0.0634 & 12.453 & 3.97 & 4.143 & 3.186 & 96.814 \\
Balangtieng & 53 & 26.33 & 0.0356 & 16.772 & 5.76 & 5.691 & 4.678 & 95.322 \\
Tino & 24 & 13.25 & 0.0592 & 7.437 & 2.11 & 3.691 & 3.095 & 96.905 \\
\hline
\end{tabular}

Sumber : Hasil Perhitungan

Tabel: 10 Verifikasi Hasil Pengembangan Model Debit Puncak $\left(\mathrm{Q}_{\mathrm{p}}\right)$ HSS Snyder

\begin{tabular}{|l|c|c|c|c|c|c|c|}
\hline Nama Sungai & $\begin{array}{c}\mathrm{A} \\
(\mathrm{km})\end{array}$ & $\begin{array}{c}\mathrm{Tp} \\
(\mathrm{km})\end{array}$ & $\mathrm{L}$ & $\begin{array}{c}\text { QpM } \\
(\mathrm{km})\end{array}$ & $\begin{array}{c}\mathrm{Q}_{\mathrm{p}} \mathrm{P} \\
(\mathrm{jam})\end{array}$ & $\begin{array}{c}\text { Penyimp } \\
(\%)\end{array}$ & $\begin{array}{c}\text { ketelitian } \\
(\%)\end{array}$ \\
\hline Bialo & 39 & 5.591 & 39 & 11.483 & 11.802 & 10.829 & 89.171 \\
Balangtieng & 53 & 6.329 & 53 & 13.886 & 11.223 & 9.986 & 90.014 \\
Tino & 24 & 4.681 & 24 & 8.667 & 10.632 & 9.817 & 90.183 \\
\hline
\end{tabular}

Sumber: Hasil Perhitungan

Tabel: 11. Verifikasi Hasil Pengembangan Model Waktu Dasar (Tb) HSS Snyder

\begin{tabular}{|l|c|c|c|c|c|c|}
\hline Nama Sungai & $\begin{array}{c}\mathrm{Tp} \\
(\mathrm{km})\end{array}$ & $\begin{array}{c}\mathrm{Q}_{\mathrm{p}} \\
(\mathrm{km})\end{array}$ & $\begin{array}{c}\text { TbM } \\
(\mathrm{jam})\end{array}$ & $\begin{array}{c}\text { TbP } \\
(\mathrm{jam})\end{array}$ & $\begin{array}{c}\text { Penyimp } \\
(\%)\end{array}$ & $\begin{array}{c}\text { ketelitian } \\
(\%)\end{array}$ \\
\hline Bialo & 5.591 & 6.802 & 13.754 & 13.836 & 12.842 & 87.158 \\
Balangtieng & 6.329 & 8.223 & 20.641 & 20.951 & 19.966 & 80.034 \\
Tino & 4.681 & 10.632 & 9.788 & 11.236 & 10.364 & 89.636 \\
\hline
\end{tabular}

Sumber: Hasil Perhitungan

Penelitian ini mengkaji sejumlah DAS yang diduga berpengaruh terhadap penyesuaian model HSS untuk kondisi sungai-sungai di Sulawesi selatan. Dari hasil analisis ditemukan beberapa karakteristik DAS dimana bersamaan dengan,A,L,Lc (yang merupakan parameter utama Snyder) membentuk model hidrograf satuan sintetis dengan tingkat hubungan yang sangat tinggi. Karakteristik DAS tersebut meliputi S,Wr.

\section{Model Waktu Puncak (Tp)}

Dari hasil pemodelan waktu puncak HSS Snyder sebagai fungsi karakteristik DAS sungai-sungai di Sulawesi Selatan di peroleh dengan persamaan:

$\mathrm{Tp}=44.2588 . \mathrm{L}^{-0.669} . \mathrm{Lc}^{0.0817} \cdot \mathrm{S}^{-0.0093} \cdot \mathrm{Wr}^{0.2224}$

Dengan $\mathrm{R}^{2}=99.1 \%, \mathrm{R}=99.6 \%$ dan $(\mathrm{SE} \ln \mathrm{Tp})=0.1293$ jam. Faktor penting yang menentukan besarnya waktu puncak untuk model HSS Snyder pada sungai di Sulawesi Selatan adalah,S dan Wr selain dari faktor utama L dan Lc. Lebih rinci paramete karakteristik DAS tersebut dapat dijelaskan sebagai berikut:

a. Parameter S

Pemakaian parameter S didasarkan atas keterkaitan antara waktu pengaliran dengan kecepatan aliran.

Semakin cepat aliran maka waktu pengaliran semakain singkat. Dengan kemiringan dasar saluran yang besar maka alairan akan lebih cepat. Sehingga para pakar hidrolik selalu mencantumkan parameter kemiringan dasar saluran untuk menghitung kecepatan aliran, diantaranya yang dirumuskan oleh Manning dan Chezy

Manning $V=1 / \mathrm{n} \cdot \mathrm{R}^{2 / 3} \cdot \mathrm{S}^{1 / 2}$

Chezy $\mathrm{V}=\sqrt{R . S}$ 
Dengan demikian parameter S cukup berpengaruh terhadap penentuan waktu puncak banjir.

b. Parameter $\mathrm{Wr}$

Hampir semua peneliti model hidrograf senantiasan memasukan jarak. Hanya model HSS Gama I yang memasukan faktor lebar ke dalam bentuk persamaan waktu naik, dimana faktor lebr merupkan perbandingan lebar DAS yang diukur pada $0.75 \mathrm{~L}$ dan $0.25 \mathrm{~L}$.

Pada kenyataan air yang masuk ke suangai dari suatu catchment area tidak hanya berasal dari bagian hulu sungai yang bersangkutan. Proses masuknya limpasan dimungkinkan berasal dari arah kiri dan kanan sungai. Namun demikian parameter $\mathrm{Wr}$ yang merupakan jarak tempuh limpasan langsung akibat hujan dari arah melintang sungai dianggap cukup berpengaruh terhadap besaran waktu puncak. Dari hasil analisis parameter ini cukup signifikan di dalam model untuk menentukan waktu puncak.

\section{Model Debit Puncak (Qp)}

Dari hasil pemodelan debit puncak HSS Snyder sebagai fungsi karakteristik DAS sungai-sungai di Sulawesi Selatan diperoleh dengan persamaan:

$Q p=0,9246 . A^{-0,00393} \cdot T_{p}^{-1.00933} . L 1.16$

Dengan $\mathrm{R}^{2}=97.9 \%, \mathrm{R}=99.1 \%$ dan $(\mathrm{SE} \ln \mathrm{Qp})=0.7846 \mathrm{~m}^{3} / \mathrm{det}$

Faktor-faktor penting yang menentukan besarnya debit puncak untuk model HSS Snyder pada sungaisungai di Sulawesi Selatan adalah L. Parameter L dikombinasikan dengan parameter utama A dan Tp. Volume air yang mengalir melalui tempat pengukiuran merupakan air yang dikuras dari suatu DAS . Sehingga terlihat bahwa dalam hal ini sangat tergantung pada luas DAS dan panjang sungai. Pada debit puncak panjang sungai bukan sebagai variabel jarak tempuh sebagaimana disebutkan dalam model waktu puncak. Panjang sungai disini berperan sebagai faktor pembawa (mengalirkan) volume air/banjir yang dikuras dari suatu DAS. Panjang suangai merupakan suatu unsur pokok pembentuk luas DAS, secara umum dapat dikatakan bahwa semakin besarL, maka semakin besar pula A.

\section{Model Waktu Dasar (Tb)}

Dari pemodelan, Waktu Dasar HSSnyder sebagai fungsi karakteristik DAS sungai-sungai di Sulawesi selatan dapat diperoleh dengan persamaan:

$$
\mathrm{Tb}=0.0625 . T \mathrm{p}^{2.76} \cdot \mathrm{Qp}^{0.336}
$$

Dengan $\mathrm{R}^{2}=99.7 \%, \mathrm{R}=99.9 \%$ dan $(\mathrm{SE} \ln \mathrm{Tb})=0.1084 \mathrm{jam}$

Dengan menggunakan rumus-rumus dari model regresi terpilih untuk menghitung unsur hidrograf satuan pada sungai Bialo, sungai Balangtieng dan sungai Tino maka dapat diperoleh besarnya tingkat keandalan model sebagai berikut:

\section{- Sungai Bialo}

Waktu Puncak $(\mathrm{Tp})=96.814 \%$

Debit Puncak $(\mathrm{Qp})=89.171 \%$

Waktu Dasar $(\mathrm{Tb})=87.158 \%$

\section{- Sungai Balangtieng}

Waktu Puncak $(\mathrm{Tp})=95.252 \%$

Debit Puncak $(\mathrm{Qp})=90.014 \%$

Waktu Dasar $(\mathrm{Tb})=80.043 \%$
- Sungai Tino

Waktu Puncak $(\mathrm{Tp})=96.906 \%$

Debit Puncak $(\mathrm{Qp})=90.183 \%$

Waktu Dasar $(\mathrm{Tb})=89.636 \%$

Untuk mendapatkan lengkung hidrografnya dalam penelitian ini menggunakan titik-titik bantu $\mathrm{W}_{10}$ sampai denga $\mathrm{W}_{90}$ yang sudah disesuaikan dengan karakteristik yang ada seperti yang ditulis pada persamaan dibawah ini:

$$
\begin{aligned}
& \mathrm{W}_{10}=9.966 \cdot \mathrm{A}^{-0.000534} \cdot \mathrm{Qp}^{0.126} \\
& \mathrm{~W}_{20}=5.508 \cdot \mathrm{A}^{-0.0011} \cdot \mathrm{Qp}^{0.253} \\
& \mathrm{~W}_{30}=3.221 . \mathrm{A}^{-0.0016} \cdot \mathrm{Qp}^{0.379} \\
& \mathrm{~W}_{40}=9.966 . \mathrm{A}^{-0.00214} \cdot \mathrm{Qp}^{0.506} \\
& \mathrm{~W}_{50}=9.966 . \mathrm{A}^{-0.00267} \cdot \mathrm{Qp}^{0.632}
\end{aligned}
$$

$$
\begin{aligned}
& \mathrm{W}_{60}=9.966 . \mathrm{A}^{-0.0032} \cdot \mathrm{Qp}^{0.758} \\
& \mathrm{~W}_{70}=9.966 . \mathrm{A}^{-0.00374} \cdot \mathrm{Qp}^{0.884} \\
& \mathrm{~W}_{80}=9.966 . \mathrm{A}^{-0.00427} \cdot \mathrm{Qp}^{1.01} \\
& \mathrm{~W}_{90}=9.966 . \mathrm{A}^{-0.00481} \cdot \mathrm{Qp}^{1.14}
\end{aligned}
$$


Tabel: 12 Perbandingan Volume Hidrograf Satuan

\begin{tabular}{|c|c|c|c|c|c|c|}
\hline \multirow{3}{*}{ No } & \multirow{3}{*}{ Nama sungai } & \multicolumn{5}{|c|}{ Hidrograf Satuan } \\
\hline & & \multirow{2}{*}{$\begin{array}{l}\text { Pengamatan } \\
\text { Volume }\left(\mathrm{m}^{3}\right)\end{array}$} & \multicolumn{2}{|c|}{ Model dgn Leng Alexejaues } & \multicolumn{2}{|c|}{ Hasil Pengembangan } \\
\hline & & & Volume $\left(\mathrm{m}^{3}\right)$ & Penyimp & $\begin{array}{c}\text { Volume } \\
\left(\mathrm{m}^{3}\right)\end{array}$ & Penyimp (\%) \\
\hline 1. & Maros & 601000 & 774094.4 & 22.361 & 653120 & 7.980 \\
\hline 2. & Tallo & 369000 & 527074.3 & 29.991 & 406510 & 9.227 \\
\hline 3. & Jeneberang & 757000 & 1027408 & 26.319 & 812714 & 6.855 \\
\hline 4. & Pamukkulu & 390000 & 485089 & 19.062 & 410378.8 & 4.966 \\
\hline 5. & Allu & 121000 & 172330 & 29.786 & 135912.8 & 10.972 \\
\hline 6. & Kellara & 508291 & 617108 & 17.633 & 564410 & 9.943 \\
\hline \multicolumn{3}{|c|}{ Penyimpangan maksimum (\%) } & & 29.991 & & 10.972 \\
\hline \multicolumn{3}{|c|}{ Penyimpangan minimum (\%) } & & 17.633 & & 7.98 \\
\hline \multicolumn{3}{|c|}{ Penyimpangan rata-rata (\%) } & & 24.282 & & 8.324 \\
\hline
\end{tabular}

Sumber: Hasil Perhitungan

Tabel: 13 Perbandingan HSS Snyder dengan Hasil Pengembangan Model HSS Snyder di Sulawesi Selatan

\begin{tabular}{|c|c|c|c|c|}
\hline HSS Snyder & Espey,Altman,Geaves & Goles & Harisiswoyo & Muhamad Yamin \\
\hline (1938) & (1977) & Das,Hussain & $(2001)$ & $(2004)$ \\
\hline $\mathrm{tp}=\mathrm{Ct} .(\mathrm{L} \cdot \mathrm{Lc})^{0.3}$ & $\operatorname{Tp}_{0.18}=3.1 \quad \mathrm{~L}^{1.57}{ }^{0.23} \cdot \mathrm{S}^{-0.25} \cdot \mathrm{I}^{-}$ & $\begin{array}{l}\text { tp }=1.13 \mathrm{x} \quad \text { (L.Lc/ } \\
\sqrt{S})^{0.2769}\end{array}$ & $\mathrm{Tp}=\left(\mathrm{Ct} .\left(\mathrm{L}^{9.313} \cdot \mathrm{Lc}^{1.3467}\right)^{0.3}\right.$ & $\begin{array}{l}\mathrm{T}_{\mathrm{p}}=44.259 \cdot \mathrm{L}^{-0.067} \cdot \mathrm{L}_{\mathrm{c}}^{0.0822} . \\
\mathrm{S}^{0.0093} \cdot \mathrm{W}_{\mathrm{r}}^{0.2224}\end{array}$ \\
\hline $\mathrm{Qp}=2.78 . \mathrm{Cp} \cdot \mathrm{A} / \mathrm{tp}$ & $\mathrm{Qp}=31.62 \times 10^{3} \cdot \mathrm{ATp}^{-0.95}$ & $\begin{array}{l}\mathrm{Qp}=0.315 . \mathrm{A}^{0.93} . \\
\mathrm{S}^{0.53}\end{array}$ & $\mathrm{Qp}=\mathrm{Cp}\left(\mathrm{A} / \mathrm{T} \mathrm{p}^{1.6032}\right)^{0.5194}$ & $\begin{array}{l}\mathrm{Q}_{\mathrm{p}}=0.925 \cdot \mathrm{A}^{-0.00393} \cdot \mathrm{T}_{\mathrm{p}}^{-} \\
1.00933 \cdot \mathrm{L}^{1.160}\end{array}$ \\
\hline $\begin{array}{l}\mathrm{Tb}=72+3 . t \mathrm{p} \\
\mathrm{Tb}=5.56 / \mathrm{qpR} \\
\mathrm{Ct}=0.90-3.00 \\
\mathrm{Cp}=0.90-1.40\end{array}$ & $\mathrm{~Tb}=125.89 \times 103 . \mathrm{AQp}^{0.59}$ & & $\begin{array}{l}\mathrm{Tb}=2.7832 \cdot \mathrm{A}^{0.375} \\
\mathrm{Qp}^{-0.57} \cdot \mathrm{L}^{0.436}\end{array}$ & $\mathrm{~T}_{\mathrm{b}}=0.0625 . \mathrm{T}_{\mathrm{p}}^{2.76} \cdot \mathrm{Q}_{\mathrm{p}}^{0.336}$ \\
\hline $\mathrm{W}_{50}=2 \cdot 14 \cdot(\mathrm{Qp} / \mathrm{A})^{-}$ & $\underset{0.92}{\mathrm{~W} 50}=116.22 \times 10^{3} \cdot \mathrm{Aqp}^{-}$ & & $\begin{array}{c}\mathrm{W} 50=0.1054 .^{\mathrm{A} 1} \cdot 229 \\
\mathrm{Qp}^{-1.227}\end{array}$ & 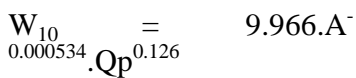 \\
\hline \multirow{4}{*}{ 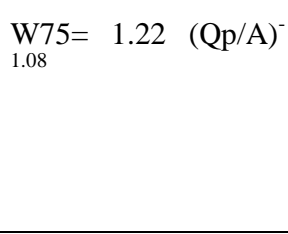 } & $\mathrm{W} 75=3.24 \times 10^{3} . \mathrm{Aqp}^{-0.78}$ & & $\mathrm{~W} 75=0.0809 .^{\mathrm{Al}} \cdot 128$. & $\mathrm{W}_{30}=3.221 . \mathrm{A}^{-0.0016} \cdot \mathrm{Qp}^{0.379}$ \\
\hline & & & & $\begin{array}{l}\mathrm{W}_{50} \\
0.00267 \\
\mathrm{Qp}^{0.632}\end{array}$ \\
\hline & & & & 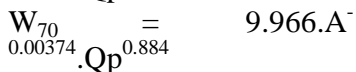 \\
\hline & & & & $\mathrm{W}_{90}=9.966 \cdot \mathrm{A}^{-0.00481} \cdot \mathrm{Qp}^{1.14}$ \\
\hline
\end{tabular}

Keterangan :

- Snyder Lokasi Penelitian sejumlah sungai di Kawasan Pegunungan Appalchian Amerika Serikat (Luas DAS $30-30.000 \mathrm{~km}^{2}$ )

- Espey,Altman,Graves Lokasi Penelitian 41 sungai di Amerika Serikat (Luas DAS 36-38.850 km²) Goles,Das dan Hussain Lokasi Penelitian sejumlah DAS di India dengan Luas DAS dibawah $700 \mathrm{~km}^{2}$ Hari Siswoyo Lokasi Penelitian di beberpa DAS di Jawa Timur dengan luas DAS di bawah $700 \mathrm{~km}^{2}$

- Muhamad Yamin Lokasi Penelitia Sungai-sungai di Sulawesi Selatan (Luas DAS $121-757 \mathrm{~km}^{2}$ )

\section{SIMPULAN DAN SARAN}

\section{Simpulan}

Dari hasil penelitian yang dapat disimpulkan sebagai berikut:

1. Bentuk dan unsur-unsur hidrograf satuan yang diturunkan dari kasus banjir pengamatan untuk sungaisungai di Sul-Sel dengan melihat hasil pemodelan untuk parameter pada rumusan Snyder perlu dikombinasikan dengan sejumlah karakteristik DAS yang berpengaruh terhadap akurasi pemakaian rumus Snyder untuk sungai utama (S) dan lebar rata-rata DAS sepanjang sungai utama yang rata-rata dari lebar DAS pada 1/4 panjang sungai ,3/4 panjang sungai dan pada titik disungai utama yang terdekat dengan titik berat DAS (Wr) dari kombinasi dari kedua parameter tersebut dengan parameter dari 
Snyder diperoleh model untuk bentuk persamaan Snyder Modifikasi sebagai fungsi karakteristik DAS sungai-sungai di Sul-Sel.

2. Pemakaian model kurva Alexejeyev tidak dapat mengikuti fluktuasi hidrograf yang dihasilkan dari penelitian ini, dimana dari kontrol volume diperoleh nilai penyimpangan sangat besar. Mengatasi masalah diatas maka agar dapat sesuai dengan hasil pemodelan,penggambaran hidrograf didasarkan atas bentuk kurva yang dibuat oleh Snyder dengan menggunakan titik bantu W50 dan W75, akan tetapi dalam penelitian ini penulis menggunakan titik-titik bantu $\mathrm{W}_{10}$ sampai $\mathrm{W}_{90}$ yang telah disesuaikan dengan kondisi setempat. Titik - titik tersebut dihubungkan sehingga membentuk suatu hidrograf.

3. Dari ke 8 DAS yang dimodelkan hanya 6 DAS yang bisa mengikuti model, hal ini disebabkan karena waktu tempuh dari kedua DAS tersebut jauh perbedaannya dan model tidak bisa digunakan untuk DAS Tamanroya dan Tangka.

4. Dari model terpilih seperti disajikan dalam tabel 11 dilakukan uji kendala. Uji ini dilakukan dalam 2 tahapan pengecekan model, yaitu kalibrasi yang bertujuan untuk memeriksa ketepatan parameter hidrograf sat satuan yang dimodelkan, dan verifikasi yang bertujuan untuk membuktikan bahwa model sudah sesuai dengan yang ada di lapangan tanpa mengubah atau mengatur data.

\section{Saran-saran}

Untuk lebih mendekati kondisi yang sebenarnya perlu dilakukan generalisasi pada lokasilokasi yang lebih luas dan verifikasi pada sejumlah lokasi lainnya. Disamping itu perlu dilakukan peningkatan hasil penelitian dengan menggunakan kuantitas data yang legih banyak dan kualitas data yang yang lebih baik agar lebih mengakuratkan hasil penelitian yang diperoleh.

\section{DAFTAR PUSTAKA}

Bisri,MdanAndarwayanti, Ussy 1995. Kalibrasi Parameter HidrografSatuanSintetis Snyder (StudiKasus di sub DAS Lesti,GentengdanAmporong) Prosiding PIT X HATHI Cabang Ujung Pandang

Chow,V.T.,Maidment,D.R,andmays,LW .1998. Applied Hydrology Singapora. Mc.Graw-Hill

HariSiswoyo 2001,Pengembangan HSS Snyder untuk Sungai-sungai di JawaTimur. Thesis Magister Teknik Institusi Teknologi Sepuluh Nopember Surabaya

Sri Harto, 1995a, HidrologiTeknikInstitutTeknologi Bandung

1995b, Pengkajian Sifat Dasar Hidrograf Satuan Sungai-sungai di Pulau Jawa untuk

Perkiraan Banjir. Desertasi Program DoktorUniversitas Gajah Mada Yogyakarta 